\title{
EFEKTIVITAS METODE THINK PAIR SHARE TERHADAP MINAT DAN HASIL BELAJAR SISWA
}

\author{
Ahmad Masduki 1)* \\ ${ }^{1}$ SMK YPE Nusantara Slawi, Tegal \\ *E-mail: ahmad.masduki69@gmail.com
}

\begin{abstract}
The purpose of this study was to determine the increase in interest and student learning outcomes of class XI OTKP-1 SMK YPE Nusantara Slawi Academic Year 2019/2020 in the subject of Islamic Religious Education (PAI) using a Think Pair Share (TPS) type cooperative approach. The research method uses a classroom action research method with two cycles. Each cycle involved 26 students who were divided into six groups. Each cycle consists of four stages, namely planning, implementing the action, observing, and reflecting. Data analysis used comparative descriptions of initial conditions, cycle I, and cycle II for interest variables in learning and learning outcomes. The results showed that applying the TPS-type cooperative learning model could increase student interest in learning and learning outcomes. Increased interest in learning in the first cycle of the first meeting reached 52\%, and the second meeting reached 63\%. The first meeting reached $76.66 \%$ in the second cycle, and the second meeting reached $88.33 \%$. Learning outcomes increased from $34.61 \%$ to $80.77 \%$ in cycle I and $65.39 \%$ in cycle II.
\end{abstract}

Keywords: Think Pair Share, Interest in Learning, Learning Outcomes

\begin{abstract}
Abstrak
Tujuan penelitian ini adalah untuk mengetahui peningkatan minat dan hasil belajar siswa kelas XI OTKP-1 SMK YPE Nusantara Slawi Tahun Ajaran 2019/2020 pada mata pelajaran Pendidikan Agama Islam (PAI) dengan menggunakan tipe Think Pair Share (TPS). pendekatan kooperatif. Metode penelitian menggunakan metode penelitian tindakan kelas dengan dua siklus. Setiap siklus melibatkan 26 siswa yang dibagi menjadi enam kelompok. Setiap siklus terdiri dari empat tahapan yaitu perencanaan, pelaksanaan tindakan, observasi, dan refleksi. Analisis data menggunakan deskripsi komparatif kondisi awal, siklus I, dan siklus II untuk variabel minat belajar dan hasil belajar. Hasil penelitian menunjukkan bahwa penerapan model pembelajaran kooperatif tipe TPS dapat meningkatkan minat belajar dan hasil belajar siswa. Peningkatan minat belajar pada siklus I pertemuan pertama mencapai $52 \%$, dan pertemuan kedua mencapai $63 \%$. Pertemuan pertama mencapai $76,66 \%$ pada siklus II, dan pertemuan kedua mencapai $88,33 \%$. Hasil belajar meningkat dari 34,61\% menjadi $80,77 \%$ pada siklus I dan $65,39 \%$ pada siklus II.
\end{abstract}

Kata kunci: Think Pair Share, Minat Belajar, Hasil Belajar

\section{PENDAHULUAN}

Penelitian yang penulis lakukan ini dilatarbelakangi masalah rendahnya minat dan hasil belajar pada materi pendidikan agama Islam yang banyak memuat ayat-ayat al-Qur'an maupun Hadits yang dipengaruhi oleh faktor eksternal maupun faktor internal. Faktor eksternal di antaranya yaitu siswa ada kecenderungan untuk pembelajaran satu arah atau berpusat pada guru. Sedangkan faktor internalnya adalah 
keterbatasan dalam kemampuan siswa sendiri dalam menulis, membaca, dan menghafal, serta memahami kandungan al-Qur'an maupun Hadits.

Siswa banyak juga yang mengalami kesulitan pemahaman materi yang bersifat abstrak, sehingga masih mengalami kesulitan dalam pencapaian hasil belajar yang maksimal. Hal ini penulis alami dalam pembelajaran pendidikan agama Islam di kelas XI OTKP-1 yang hasil evaluasinya masih banyak yang belum mencapai target ketuntasan belajar minimal pada angka 75. Masalah internal ini bisa jadi dimungkinkan dari faktor pembelajaran yang masih didominasi oleh guru dalam melakukan pembelajaran dengan dengan berpusat pada guru (indirect learning).

Permasalahan ini bisa dicarikan solusi dengan cara perbaikan pendekatan Kondisi yang demikian dimungkinkan siswa kurang terangsang aktifnya dikarenakan kurang menantang pembelajarannya bagi siswa atau terasa jenuh. Hal yang demikian alternatifnya yaitu memvariatifkan model atau pendekatan pembelajarannya yang mampu merangsang keaktifan siswa sehingga menumbuhkan minat siswa untuk belajar pendidikan Agama Islam.

Kondisi guru yang belum mencoba untuk menerapkan metode atau pendekatan yang lebih menarik dapat disimpulkan menjadi faktor yang menyebabkan permasalahan rendahnya minat dan hasil belajar siswa dalam pembelajaran pendidikan agama Islam dalam pembelajaran yang mampu menciptakan keaktifan dan menyenangkan bagi siswa dalam pembelajaran pendidikan Agama Islam. Penulis dalam hal ini berminat untuk mencoba menerapkan model atau pendekatan yang membuat siswa merasa tidak ada kesulitan dalam pembelajaran pendidikan Agama Islam.

Pendekatan kooperatif tipe Think Pair Share dalam beberapa referensi merupakan salah satu pendekatan yang bisa menciptakan pembelajaran hidup dikarenakan keaktifan siswa dengan suasana menyenangkan dan tidak ada rasa tekanan bagi siswa sehingga hasil belajar dapat meningkat. Meskipun demikian pendekatan Think Pair Share ini membutuhkan kreatifitas guru dan kreatifitas siswa untuk tekun dan terampil.

Berdasarkan latar belakang masalah tersebut penulis akan mencoba untuk menerapkan pendekatan kooperatif tipe Think Pair Share dengan bantuan lembar kerja siswa sebagai upaya untuk meningkatkan minat dan hasil belajar pendidikan 
agama Islam bagi siswa kelas XI OTKP-1 semester gasal SMK YPE Nusantara Slawi tahun pelajaran 2019/2020.

\section{KAJIAN TEORI}

Minat dapat diartikan sebagai kecenderungan untuk selalu memperhatikan dan mengingat secara terus menerus terhadap sesuatu (kegiatan, orang, atau benda) yang disertai dengan keinginan untuk mengetahui, mempelajari dan membuktikannya lebih lanjut. Hal ini sebagaimana pendapat Alisuf Sabri, bahwa Minat (interest) adalah kecenderungan untuk selalu memperhatikan dan mengingat sesuatu secara terus menerus. Minat ini erat kaitannya dengan perasaan terutama perasaan senang, karena itu dapat dikatakan minat itu terjadi karena sikap senang kepada sesuatu. Orang yang minat kepada sesuatu berarti ia sikapnya senang kepada sesuatu itu (Alisuf Sabri Idi, 1996,84).

Rendahnya minat seorang anak terhadap suatu pelajaran akan menimbulkan kesulitan belajar. Belajar tidak disertai minat mungkin tidak sesuai dengan bakat, tidak sesuai dengan kebutuhan, tidak sesuai dengan kecakapan, tidak sesuai dengan tipetipe khusus anak yang menimbulkan problema pada dirinya. Karena itu pelajaran pun tidak pernah terjadi proses dalam otak, akibatnya timbul kesulitan (Abu Ahmadi dan Widodo Supriyono Idi, 2004, 83).

Dick dan Reiser mengemukakan bahwa hasil belajar merupakan kemampuankemampuan yang dimiliki siswa sebagai hasil kegiatan pembelajaran, yang terdiri atas empat jenis, yaitu pengetahuan, keterampilan intelektual, keterampilan motor, dan sikap (Sumarno Idi, 2011). Sedangkan pendapat yang lain yang dikemukakan oleh Bloom dan Kratwohl bahwa hasil belajar merupakan perubahan tingkah laku yang secara umum dapat dikelompokkan ke dalam tiga kategori yaitu ranah kognitif, afektif, dan psikomotor (Rusman Idi,1994,29). Jadi pengertian hasil belajar dari beberapa pendapat tersebut dapat disimpulkan bahwa hasil belajar merupakan kemampuan dalam pengetahuan, ketrampilan, dan sikap.

Pembelajaran Kooperatif adalah Model Pembelajaran yang mengutamakan kerja sama untuk mencapai tujuan pembelajaran. Pembelajaran Kooperatif (Cooperative learning) merupakan bentuk pembelajaran dengan cara siswa belajar dan bekerja dalam kelompok-kelompok kecil secara kolaboratif, yang anggotanya terdiri dari 4 
sampai 6 orang, dengan struktur kelompok yang bersifat heterogen (Abdul Majid Idi, $2013,174)$.

Dengan demikian Pembelajaraan Kooperatif merupakan model pembelajaran dengan setting kelompok-kelompok kecil dengan memperhatikan keberagaman anggota kelompok sebagai wadah siswa bekerja sama dan memecahkan suatu masalah melalui interaksi sosial dengan teman sebayanya, memberikan kesempatan pada peserta didik untuk mempelajari sesuatu dengan baik dan ia menjadi narasumber bagi teman yang lain. Model pembelajaran Think Pair Share merupakan salah satu model pembelajaran kooperatif. Metode yang sederhana, namun sangat bermanfaat ini dikembangkan pertama kali oleh Frank Lyman dari University of Maryland.

Think Pair Share memiliki prosedur yang ditetapkan secara eksplisit untuk memberi waktu lebih banyak kepada siswa untuk berpikir, menjawab, dan saling membantu satu sama lain. Seandainya guru baru saja menyelesaikan suatu penyajian singkat, atau siswa telah membaca suatu tugas, atau suatu situasi penuh teka-teki telah dikemukakan, sekarang guru menginginkan siswa memikirkan lebih mendalam tentang apa yang telah dijelaskan atau dialami. Ia memilih untuk menggunakan strategi think-pair-share sebagai pengganti Tanya jawab seluruh kelas. (Abdul Majid Idi, 2013,191),

Berdasakan kajian teori dan kerangka berfikir tersebut, hipotesis tindakan kelas ini adalah : (1) Penerapan Model Pembelajaran Kooperatif Tipe Think Pair Share dapat meningkatkan minat belajar pendidikan agama Islam pada siswa kelas XI OTKP-1 SMK YPE Nusantara Slawi Kabupaten Tegal Tahun Pelajaran 2019/2020. (2) Penerapan Model Pembelajaran Kooperatif Tipe Think Pair Share dapat meningkatkan hasil belajar pendidikan agama Islam pada siswa kelas XI OTKP-1 SMK YPE Nusantara Slawi Kabupaten Tegal Tahun Pelajaran 2019/2020.

\section{METODE}

Desain penelitian ini merupakan penelitian Tindakan Kelas ini (PTK) ini dilaksanakan pada semester gasal tahun pelajaran 2019/2020, sejak bulan Agustus sampai dengan November 2019 dilaksanakan di SMK YPE Nusantara Slawi yang beralamat di Jalan MT. Haryono Kalisapu-Slawi Tegal. Siswa yang dijadikan subyek penelitian ini adalah siswa kelas XI OTKP-1 yang berjumlah 26 siswa. 
Pengumpulan data pada penelitian ini menggunakan teknik dokumentasi, angket dan tes. Alat pengumpulan data menggunakan dokumen daftar nilai untuk data hasil belajar kondisi awal, lembar angket untuk mengetahui tingkat minat belajar siswa, dan tes hasil belajar PAI siklus I dan II untuk mengetahui tingkat peningkatan hasi belajar PAI.

Triangulasi merupakan teknik pemeriksaan validitas data dengan memanfaatkan sarana di luar data itu untuk keperluan pengecekan atau pembandingan data itu (Moleong Idi, 1995,178). Validitas dari tiga komponen baik peneliti, siswa maupun observer. Analisis data pada penelitian ini menggunakan analisis menggunakan analisis deskriptif, yaitu membandingkan hasil observasi kegiatan pembelajaran antar siklus dan refleksi. Hasil belajar dianalisis dengan analisis deskriptif yaitu membandingkan nilai dari penilaian antar siklus maupun dengan indikator kinerja.

Penelitian ini merupakan penelitian tindakan yang dilaksanakan di dalam kelas atau biasa disebut Classroom Action Research yang terdiri dari dua siklus. Penelitian tindakan kelas ini bersifat parsitipatif karena melibatkan guru mata pelajaran sebagai guru dan guru yang melakukan penelitian selama proses pembelajaran. Empat kegiatan utama yang ada pada setiap siklus, yaitu : 1) perencanaan, 2) tindakan, 3) pengamatan, 4) refleksi, (Arikunto Idi, 2006,74). Dengan demikian prosedur penelitian ini memiliki siklus perencanaan - tindakan - pengamatan - refleksi - dan revisi dan seterusnya sehingga tercapai tujuan yang diinginkan dengan tindakan yang paling efektif. Siklus 2 dikembangkan berdasarkan refleksi yang diperoleh dari siklus 1.

\section{HASIL DAN PEMBAHASAN}

\section{Deskripsi Kondisi Awal}

Hasil pengamatan menunjukkan bahwa rata-rata minat siswa adalah dapat dilihat dari hasil ulangan pada pra siklus. Hasil ulangan harian PAI-BP pada kelas XI OTKP-1 pada pra siklus menunjukkan angka rata-rata 64,61. Dengan 9 siswa $(34,61 \%)$ mencapai angka tuntas di atas 75 dan 17 Siswa (65,39\%) tidak tuntas. Hal ini menunjukkan bahwa hasil belajar dan minat belajar PAI-BP masih rendah.

\section{Deskripsi Hasil Siklus I}

Pada Siklus I pembelajaran Kooperatif tipe Think Pair Share dengan jumlah 5 siswa per kelompok, diskusi berjalan baik. Namun ada sebagian siswa yang terlibat aktif dan ada sebagian siswa yang menyimak saja. Hasil siklus I pertemuan ke-1 
mencapai $52 \%$ pada tingkat kurang aktif, dan pertemuan ke-2 mencapai 63\% pada tingkat cukup aktif. Pada hasil penilaian ulangan harian hasil tes tertulis diperoleh nilai terendah 65, nilai tertinggi 90 Dan rerata 77,88. Terdapat 21 siswa $(80,77 \%)$ memperoleh nilai hasil belajar PAI-BP > 75 artinya tuntas dan 5 siswa $(19,23 \%)$ tidak tuntas. Ketuntasan belajar pada siklus I telah mencapai ketuntasan di atas $80 \%$ sehingga indikator kinerja telah tercapai pada siklus I.

Refleksi Tindakan Siklus I, Kolaborator memberi masukan dari refleksi bersama siswa untuk meningkatkan efektifitas kerjasama kelompok maka jumlah siswa dalam satu kelompok bisa diperkecil, yakni perkelompok terdiri dari 4 siswa yang awalnya 5 siswa dengan harapan setiap siswa akan semakin aktif dalam pembelajaran. Catatan penting lain dalam hasil pengodean masih bisa diefektifkan dengan membuat gambaran yang lebih spesifik per siswa, sesuai dengan teori pengodean yang lebih berkesan bagi siswa.

\section{Deskripsi Hasil Siklus II}

Pada siklus II telah dilaksanakan pembelajaran dengan menggunakan model pembelajaran Kooperatif tipe Think Pair Share dengan jumlah kelompok yang lebih kecil, pengodean lebih spesifik, membimbing siswa untuk melakukan pemetaan pengodean. Hasil aspek minat belajar PAI dilihat dari aktifitas kegiatan pada siklus II mengalami peningkatan dari cukup aktif (63\%) pada siklus I menjadi aktif $(76,66 \%)$ pada pertemuan ke-1 dan menjadi sangat aktif (88,33\%) pada pertemuan ke-2 pada siklus II. Adapun hasil belajar mencapai rerata 84,81 dengan nilai terendah 75 dan nilai tertinggi 100. Dan presentasi ketuntasan pada siklus II mencapai 100\% tuntas dari 26 siswa. Data ini menunjukkan bahwa pasa siklus II telah tercapai $84,81 \%$ dan ini telah memenuhi indikator kinerja penelitian yaitu 80\% siswa mencapai ketuntasan pada siklus II.

\section{Pembahasan}

Hasil pengamatan menunjukkan bahwa penggunaan model pembelajaran kooperatif tipe Think Pair Share berdampak pada minat dan hasil belajar siswa. Peningkatan persentasi minat belajar PAI-BP pada siklus I pertemuan ke-1 mencapai 52\% (kriteria kurang aktif) dan pertemuan ke-2 mencapai 63\% (kriteria cukup aktif), ini menunjukkan adanya peningkatan 11\%. Pada siklus II capaian presentasi meningkat dibanding pada siklus I. Pada siklus II pertemuan ke-1 mencapai 76,66\% (kriteria aktif) dan pertemuan ke-2 mencapai 88,33\% (kriteria sangat aktif), ini 
menunjukkan adanya peningkatan 11,67\%. Dari pertemuan pertama sampai terakhir presentasi capaian atifitas kegiatan selalu meningkat.

Melalui model kooperatif tipe Think Pair Share dengan bantuan lembar kerja siswa dapat meningkatkan minat belajar siswa. Ketika tingkat minat siswa dalam pembelajaran PAI-BP dengan model pembelajaran kooperatif tipe Think Pair Share diukur dengan tanggapan siswa melalui angket, hasilnya dapat dilihat pada tabel berikut:

Tabel 1.

Tingkat Minat Siswa Belajar PAI-BP

\begin{tabular}{llcl} 
Tingkat Minat Belajar & Interval Nilai & Jumlah Siswa & Presentase (\%) \\
& & & \\
Sangat Tinggi & $36-40$ & 2 & $7,69 \%$ \\
Tinggi & $31-35$ & 24 & $92,31 \%$ \\
Sedang & $21-30$ & - & - \\
Rendah & $10-20$ & - & - \\
Jumlah & & 26 & $100 \%$ \\
\hline
\end{tabular}

Berdasarkan tabel 1, ada 7,69\% atau 2 orang siswa yang medapat skor antara 36-40 dengan tingkat minat belajar sangat tinggi. Dan 92,31\% atau 24 orang siswa mendapat skor antara 31-35 dengan tingkat minat belajar yang tinggi. Dalam hal hasil belajar siswa mata pelajaran pendidikan agama Islam dan budi pekerti dapat dilihat pada tabel berikut:

Tabel 2.

Perbandingan Hasil Belajar PAI-BP Antar Siklus

\begin{tabular}{lcccl}
\hline & $\begin{array}{c}\text { Kondisi } \\
\text { Awal }\end{array}$ & Siklus I & $\begin{array}{c}\text { Siklus } \\
\text { II }\end{array}$ & $\begin{array}{c}\text { Refleksi dari } \\
\text { kondisi awal ke } \\
\text { kondisi akhir }\end{array}$ \\
Jumlah nilai & 1680 & 2.025 & 2.205 & Naik 525 \\
Rerata nilai & 64,61 & 77,88 & 84,81 & Naik 20,2 \\
Nilai terendah & 55 & 65 & 75 & Naik 20 \\
Nilai tertinggi & 80 & 90 & 100 & Naik 20 \\
Jumlah siswa yang tuntas & 9 & 21 & 26 & Naik 17 \\
Jumlah siswa yang tidak tuntas & 17 & 5 & 0 & \\
Presentase siswa yang tuntas & $34,61 \%$ & $80,77 \%$ & $100 \%$ & Naik 65,39\% \\
Presentase siswa yang tidak & $65,39 \%$ & $19,23 \%$ & $0 \%$ & \\
tuntas & & & & \\
\hline
\end{tabular}


Berdasarkan perbandingan data kondisi awal, siklus I dan siklus II, ketuntasan hasil belajar PAI-BP mengalami peningkatan dari 34,61\% menjadi 100\% pada kondisi akhir dengan kenaikan 65,39\%. Dengan demikian tujuan penelitian untuk mengetahui penggunaan model pembelajaran kooperatif tipe Think Pair Share (TPS) dengan berbantuan lembar kerja siswa terbukti dapat meningkatkan minat dan hasil belajar PAI-BP pada materi menjalin kebersamaan dan kerukunan melalui toleransi, dan materi tentang memegang teguh keyakinan kepada al-Qur'an.

\section{SIMPULAN DAN SARAN}

\section{Simpulan}

Terjadi perubahan minat siswa dalam pembelajaran dengan model pembelajaran kooperatif tipe Think Pair Share (TPS) dengan bantuan lembar kerja siswa untuk meningkatkan hasil belajar PAI-BP bagi siswa kelas XI OTKP-1 SMK YPE Nusantara Slawi semester ganjil berkualifikasi sangat aktif pada siklus I 52\% menjadi 63\%, pada siklus II 76,66\% menjadi 88,33\%. Ini menunjukkan adanya peningkatan ketertarikan, keaktifan, kerjasama dan antusiasme dalam pembelajaran.

Peningkatan minat belajar PAI-BP dengan model pembelajaran kooperatif tipe Think Pair Share (TPS) dengan bantuan lembar kerja siswa untuk meningkatkan hasil belajar PAI-BP bagi siswa kelas XI OTKP-1 SMK YPE Nusantara Slawi semester ganjil terlihat hasil pernyataan siswa melalui angket di akhir kegiatan penelitian dengan tingkat minat belajar tinggi 92,31\% sejumlah 24 siswa, dan tingkat minat belajar sangat tinggi 7,69\% sejumlah 2 siswa.

\section{Saran}

Penelitian ini perlu diuji coba pada subyek lain. Perlu dilakukan pengembangan model pembelajaran kooperatif tipe Think Pair Share (TPS) dengan teknis yang berbeda. Perlu dirancang pembelajaran menggunakan pembelajaran kooperatif tipe Think Pair Share (TPS) pada tema pembelajaran yang berbeda.

\section{DAFTAR PUSTAKA}

A.M, Sardiman (2012), Interaksi \& Motivasi Belajar Mengajar, I. Jakarta: PT Raja Grafindo Persada.

Ahmadi, Abu dan Supriyono, Widodo (2004), Psikologi Belajar. Jakarta: PT Rineka Cipta. 
Arief, Armai (2002), Pengantar Ilmu dan Metodologi Pendidikan Islam. Jakarta: Ciputat Pers.

Arifin, H. M. (1991), Ilmu Pendidikan Islam. Jakarta: Bumi Aksara.

Arifin, Zainal (2012), Evaluasi Pembelajaran. Bandung: PT Remaja Rosdakarya, Arikunto, Suharsimi dkk. (2008), Penelitian Tindakan Kelas. Jakarta: PT. Bumi Aksara.

Assegaf, Abdur Rahman (2007), Pendidikan Islam di Indonesia. Yogyakarta: Suka Press.

Azhari, Akyas (2004), Psikologi Umum dan Perkembangan. Jakarta: Teraju.

Chaplin, James P. (2006), Kamus Lengkap Psikologi. Jakarta: PT RAJA GRAFINDO PERSADA.

Djamarah, Saiful Bahri dan Zain, Aswan (2006), Strategi Belajar Mengajar . Jakarta: PT Rineka Cipta.

Hamdani, Nizar Alam dan Hermana, Dody (2008), Classroom Action Research. Bandung: Rahayasa.

Ibrahim, Muslimin dkk. (2001), Pembelajaran Kooperatif. Surabaya: UNESA,

Lie, Anita (2014), Cooperative Learning. Jakarta: PT Gramedia Widiasarana Indonesia.

Majid, Abdul (2013), Strategi Pembelajaran. Bandung: PT Remaja Rosda Karya.

Purwanto, Ngalim (2010), Psikologi Pendidikan. Bandung: PT Remaja RosdaKarya.

Riyanto, Yatim. Paradigma Baru Pembelajaran. Jakarta: Kencana Prenada Media Group, 2009.

Rusman (2011), Model-model Pembelajaran Mengembangkan Profesionalisme Guru, Jakarta:Rajawali Pers.

Sanjaya, Wina (2010), Penelitian Tindakan Kelas. Jakarta: Kencana.

Shaleh, Abdul Rahman dan Abdul Wahab, Muhbib (2004), Psikologi suatu Pengantar. Jakarta: Prenada Media.

Singer, Kurt . Membina Hasrat Belajar di Sekolah. Bandung: Remadja Karya CV, 1987.

Siregar, Eveline dan Nara, Hartini (2011), Teori Belajar dan Pembelajaran. Bogor: GHALIA INDONESIA.

Slameto (2010), Belajar dan Faktor-faktor yang mempengaruhinya. Jakarta; PT Rineka Cipta. 
36 | Ahmad Masduki

Sugiyono (2012), Memahami Penelitian Kualitatif . Bandung: AlfaBeta.

Suharsaputra, Uhar (2014), Metode Penelitian Kuantitatif, Kualitatif, dan Tindakan. Bandung: PT Refika Aditama.

Supardi, Ahmad dan Syah, Wayudin (1984), Metodologi Riset. Bandung: IAIN SGD.

Syah, Muhibbin (2011), Psikologi Pendidikan dengan Pendekatan Baru. Bandung: PT Remaja Rosda Karya.

Taniredja, Tukiran (2013), Model-Model Pembelajaran inovatif dan Efektif. Bandung: Alfabeta.

Tohirin (2008), Psikologi Pembelajaran Pendidikan Agama Islam. Jakarta: PT RajaGrafindo Persada. 